\title{
Strategies to Introducing Ecotourism Concept with Social Media for College Student in Malang
}

\author{
Ida Idewa Agung Willy Pramana ${ }^{1 *}$, Amin Setyo Leksono ${ }^{2}$, Moch. Sasmito Djati \\ ${ }^{1}$ Postgraduate School, University of Brawijaya, Malang, Indonesia \\ 2Department of Biology, Faculty of Mathematics and Natural Sciences, University of Brawijaya, Malang, Indonesia
}

\begin{abstract}
In Indonesia, research about Social Media and Ecotourism is still few. Some studies in Indonesia mostly still view social media as marketing advice. In fact, social media also plays an important role in regulating the perceptions of the people who come to the ecotourism site both from the content or the ease of access. Practically this research can be used as a strategic reference by stakeholders, to be able to use Social Media as media for promotion and education. Then academically, this research can be a reference for further research on the strategy of managing ecotourism with social media. This research is a descriptive type with quantitative and qualitative approaches, with research locations in Malang. Research using an online questionnaire with Google Form. The results are, Instagram is the most used social media by students in Malang. And for the management strategy with Instagram, it can be done with an aggressive strategy that is utilizing Strength and Opportunities from Instagram such as fast, cheap, environmentally friendly and widely used by students and can be more optimized with the AISAS strategy. Step by step to Introducing Ecotourism in social media are, getting the Attention maybe with Influener or public figure, build interest with consistent post everyday, make user search about ecotourism, and get them to take action such as reading about ecotourisma, increasing their engagement ecotourism, and for the last step will make them to share the information to fellow student as social media user.
\end{abstract}

Keywords: ecotourism, facebook, Instagram, Malang, social media, strategy, student.

\section{INTRODUCTION}

Indonesia is one of a country with the highest diversity of flora and fauna. Therefore, Indonesia categorized as a mega-biodiversity country, with $25 \%$ of the species in the world [1]. With abundant resources, good management is needed, thus it can be utilized optimally and sustainable for a long time.

One of the uses of natural resources is in the tourism sector. Tourism is a variety of tourist activities, which are supported by facilities and provided by the community, entrepreneurs, government, and local government [2].

Ecotourism is a type of tourism that is included in sustainable tourism [3]. Although it has many advantages in terms of conservation, improvement in the quality of community life, and cultural preservation, ecotourism also has several weaknesses. One of them still has limited access to information. For example, market networks and infrastructure for Ecotourism management [4].

One instrument that used as a way to access information is the Internet. Or more specifically with social media. China has started using Social Media as a tool. Not only in the interests of

\footnotetext{
* Correspondence Address:

Ida Idewa Agung Willy Pramana

Email : agungwillypramana@gmail.com

Address : Postgraduate School, University of Brawijaya

Jl. Mayjen Haryono No. 169, Malang 65145.
}

marketing its exclusive location, but also trying to form perceptions of its visitors [5].

Social Media is a media which consist of three parts, i.e. infrastructure, information, and tools. It was used to produce and spread media content. Content in social media can be personal messages, news, ideas, and cultural products in digital form. Later, the role of producing and consuming media content can be individuals, organizations, or even industries [6]. In 2015, from 255 million population in Indonesia, 88.1 million were Internet users and 79 million of these internet users were active as social media users [7].

In Indonesia, research about Social Media and Ecotourism is still not done much. Most of the studies in Indonesia mostly still view social media as marketing advice, although some have started using Social Media as an educational medium. Previous research in China showed that social media also acts as a driver in social movements in society [8]. With social media, people will have a room for discussion, sharing the idea, keep in touch, etc. For a certain point, social media has a stronger side and sometimes can drive government for making policy. Social media also make people good and smart because they can share knowledge with others [8]. In addition, social media is also a very important instrument in regulating the perceptions of people who 
come to ecotourism sites both from their content or their accessibility [9].

Introducing knowledge about Ecotourism Concept become important because it can decrease pollution in tourism area that causes by Visitor. Because with knowing about Ecotourism concept, the visitor will know what they can and can't do, and also feel more involved with the preservation of the ecosystem. Visitor or tourist arrival in tourism area has a good and bad impact. The good impact is, will increase income from stakeholder and local people, and later the income can also be used to conserve tourism site. But the bad impact, the visitor will cause pollution such as emission from transportation, trash, and also deforestation because visitor comes [10].

This study conducted in Malang, because Malang has been known to be a city of education since the Colonialism era. In Malang, there are currently more than 88 colleges/universities [11]. For the number of students themselves, it is estimated that there are more than 350 thousand students, with estimated new students for University of Brawijaya in 2017/2018, around 10,000 students [12].

This study can be used practically as a strategic reference by stakeholders, to be able to use Social Media as a media for promotion and education. Then academically, this research can be a reference for further research on the strategy of managing ecotourism with social media.

The objectives in this study are to analyze the understanding of Students in Malang as social media users about ecotourism, analyzing the Social Media Platform that is most preferred by Students in Malang, and obtain appropriate strategies as one of the strategies for managing ecotourism with social media.

\section{MATERIAL AND METHOD}

This study is descriptive research with quantitative approaches. Descriptive research is a research that use to determine variable value between subjects independently without making a comparison or try to find a relation between variable [13]. Descriptive quantitative research use to understand phenomena that happened with help from the number and determine characteristic from subject [14].

This study conducted in Malang, with estimated new students for the University of Brawijaya itself in 2017/2018, around 10,000 students [12]. Currently, more than 88 colleges/universities, for the number of students estimated more than 350 thousand students in Malang [11]. So with a high amount and diverse student population, it can provide a clearer picture of how students understand about ecotourism. The study was conducted for one month, starting from May $17^{\text {th }} 2018$, to June 17 th 2018.

\section{Data Collection}

Data collection is done using Online Questionnaire via google form (here is the link: https://goo.gl/forms/LEV3Q2ulwJ4qWpT63). The questionnaire itself is an indirect data retrieval technique. The questionnaire contained a list of questions that would later have to be answered or responded by the respondents. Respondents themselves have the freedom to give answers according to their perceptions [15].

Variable that included in this questionnaire for basic information are the name, age, College, favorite social media and time spent per day in social media, Intensity Tourism Post in social media and how they feel. For Ecotourism Knowledge are, what they know about Ecotourism, Ecotourism site that they know, what social media account that provides ecotourism information, their knowledge about conservation activity at tourism site, and activity that they usually do at tourism site. And for the last section is a question about how the post in social media should be that can make them interest about Ecotourism.

For data collection in this study, it has two phases. The first phase is conducted by the Questionnaire preliminary test to find out whether the questions submitted are appropriate to achieve the desired target for three days starting from May $11^{\text {th }} 2018$, to May $14^{\text {th }} 2018$. Then after being appropriate, then spread to as many student respondents for one month starting May $17^{\text {th }} 2018$ to June $17^{\text {th }}, 2018$. Questionnaire spread using Whatsapp media, Instagram, and there are also those taken directly.

The first phase of the distribution of questionnaires is to find out the validity of the data by knowing if the question list is appropriate. In the qualitative research conducted the test is on the data. So that later, to determine whether valid or not valid with the compatibility between the data obtained with the data reported [13].

Google form is one of product from Google whose function is to help plan surveys, provide 
quizzes, and also collect information more efficiently. This form can also be directly connected with a spreadsheet in Microsoft Excel for further processing [16].

\section{Data analysis}

The final result from this study would be used to determine the strategy using the most widely used Social Media with SWOT Analysis. Step in SWOT analysis is, first identifying internal and external variables, followed by preparing relative point and ratings, then proceeding with weighting, relative point and also scores [17].

\section{RESULT}

From the retrieval of data, 138 respondents were students in Malang, with ages ranging from 19 to 30 years. Then for the most widely used social media platform by students, $79.2 \%$ of respondents use the Instagram Social Media Platform, then Facebook $8.3 \%$ and the rest are other Social Media. With $56.6 \%$ of respondents using social media more than two hours per day (Fig. 1).

Then for the respondent's understanding of ecotourism, results were obtained, from 138 respondents, $57.9 \%$ were doubtful about their understanding about ecotourism, 26.9\% knew very well, and $15.2 \%$ did not know. Then to ascertain the truth, given further questions about what ecotourism is. And the results obtained, $65.5 \%$ answered correctly, and $34.5 \%$ mistakenly interpreted ecotourism (Fig. 2).

Data analysis then continued by knowing the activities they normally do by students at tourist attractions. From the data obtained provided that respondents can choose more than one, it is known that $47.2 \%$ prefer to look exist by taking photos at tourist attractions, $42.4 \%$ participating in activities with the community, and $29.2 \%$ relaxing and not forgetting to buy some things from the gift shop (Fig. 3). This data is in accordance with previous studies which say that the younger generation is still in the search for identity and also has narcissistic traits. Many who choose to take pictures in tourist attractions are also in line with the number of students using Instagram. Where characters from Instagram are social media with a focus on Photos and Videos.

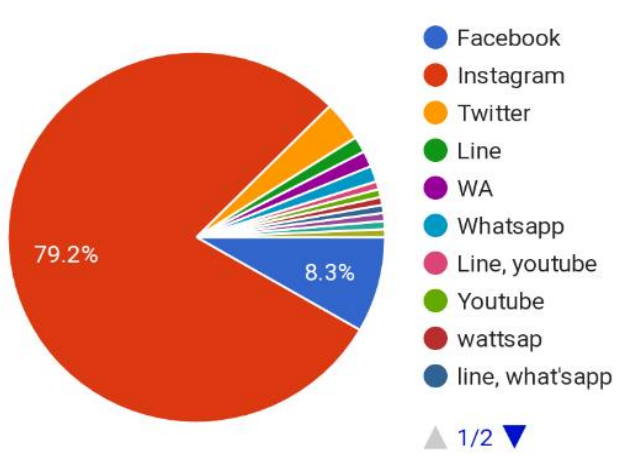

a

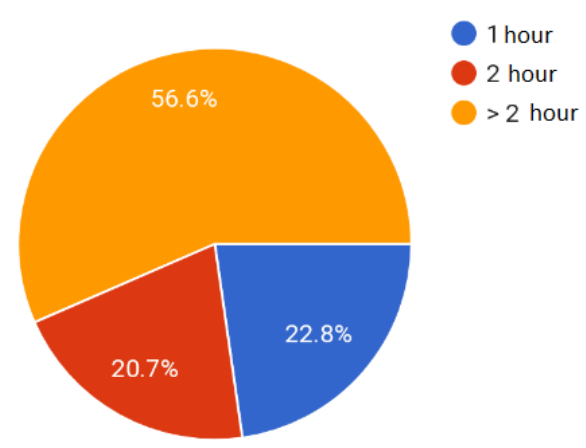

b

Figue 1. Social Media Use. a) Most Prefered Social Media by Student, b) Time spent using Social Media per day

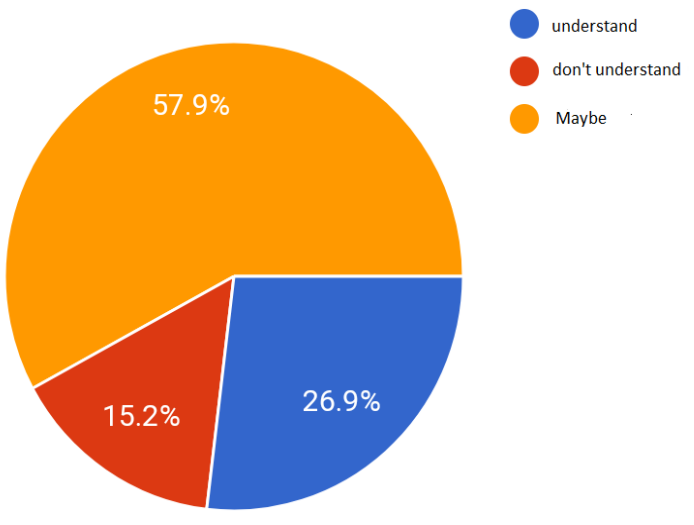

a

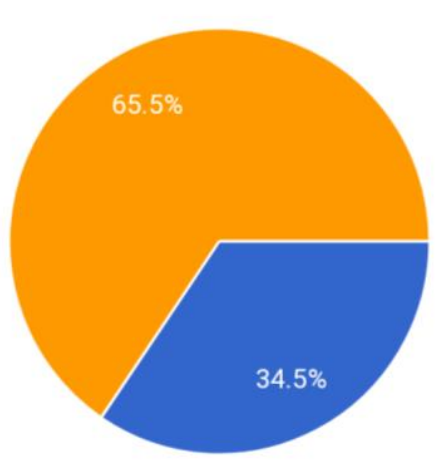

b

Figure 2. Ecotourism Knowledge. a) Understanding of Ecotourism, b) Ecotourism according to Respondent 


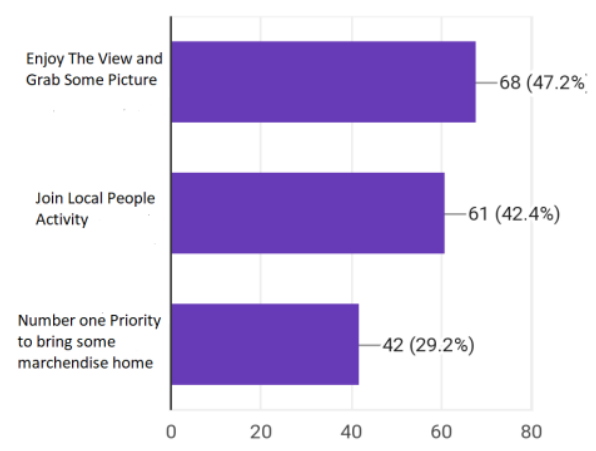

Figure 3. Normal Activities at Tourist Attraction

\section{SWOT Analysis of Instagram}

After discovered that Instagram is the most widely used social media platform, a SWOT analysis was carried out from Instagram so that the strategy could be arranged. The results of the calculation of internal and external factors (Table 1 and 2) indicate that external factors have a higher value than internal factors. This shows that internal factors are more influential than external factors in using Instagram as a strategy for ecotourism management. Both of these factors show positive values (quadrant 1 ) with coordinates 0.8 and 1.3 .
Then for the results of the Grand Matrix strategy (Fig. 4), it is in Quadrant 1 with coordinates 0.8 and 1.3. Quadrant 1 shows a favorable situation. The strategy used in Quadrant 1 is an Aggressive strategy [17]. With this aggressive strategy, it can maximize the strength of Instagram and additional opportunities to be used as a management strategy.

\section{DISCUSSION}

Instagram became preferred social media among college student with time spent more than 2 hours per day. Friendly interface that Instagram have also make it favorite for the college student to express their narcism [18]. But the interesting part is, with more than 2 hours per day on social media, the student still doubtful about their knowledge of ecotourism. That means lack of Ecotourism post in social media and with the right strategy, Instagram can be used to increase knowledge about ecotourism. An Aggressive Strategy that optimizes Strength and Opportunity is to optimize strengths and opportunities to spread the understanding of Ecotourism and create interesting Content to be seen by many people and spread faster.

Table 1. IFAS Matrix

\begin{tabular}{|c|c|c|c|c|}
\hline No & Strength Variable & Relative Point & Rating & Score \\
\hline 1 & Instagram are Ecofriendly & 0.117 & 3 & 0.351 \\
\hline 2 & More than 300 million active user & 0.159 & 4 & 0.636 \\
\hline 3 & Fast to spread information & 0.159 & 4 & 0.636 \\
\hline \multirow[t]{3}{*}{4} & Can use for chatting as well & 0.117 & 3 & 0.351 \\
\hline & $\begin{array}{ll}\text { Sub Total } \\
\end{array}$ & 0.552 & & 1.974 \\
\hline & Weakness Variable & Relative Point & Rating & Score \\
\hline 1 & Limited for Android and IOS & 0.130 & 2 & 0.260 \\
\hline 2 & Paid to Promote & 0.159 & 3 & 0.477 \\
\hline \multirow[t]{3}{*}{3} & Need to download before used & 0.159 & 3 & 0.477 \\
\hline & $\begin{array}{ll}\text { Sub Total } \\
\end{array}$ & 0.448 & & 1.214 \\
\hline & TOTAL & 1.000 & & 3.188 \\
\hline
\end{tabular}

Table 2. EFAS Matrix

\begin{tabular}{cllll}
\hline No & Opportunity Variable & Relative Point & Rating & Score \\
\hline 1 & Cheaper than Facebook & 0.107 & 3 & 0.321 \\
2 & Many Student User & 0.149 & 4 & 0.596 \\
3 & Have unique alogaritm to make certain community & 0.149 & 4 & 0.596 \\
4 & Suitable and fast to spread information among student & 0.149 & 4 & 0.596 \\
5 & Connected with other Social Media & 0.107 & 3 & 0.321 \\
\hline & & Sub Total & $\mathbf{0 . 6 6 1}$ & $\mathbf{2 . 4 3 0}$ \\
\hline & Threat Variable & 0.149 & 4 \\
\hline 1 & Can cause over visitor & 0.107 & 3 & 0.596 \\
\hline 2 & Wide and Open Challenges from other & 0.083 & 2 & 0.166 \\
\hline 3 & One day it will replaced by other Social Media & Sub Total & $\mathbf{0 . 3 3 9}$ & $\mathbf{1 . 0 8 3}$ \\
\hline & & $\mathbf{1 . 0 0 0}$ & $\mathbf{3 . 5 1 3}$ \\
\hline
\end{tabular}




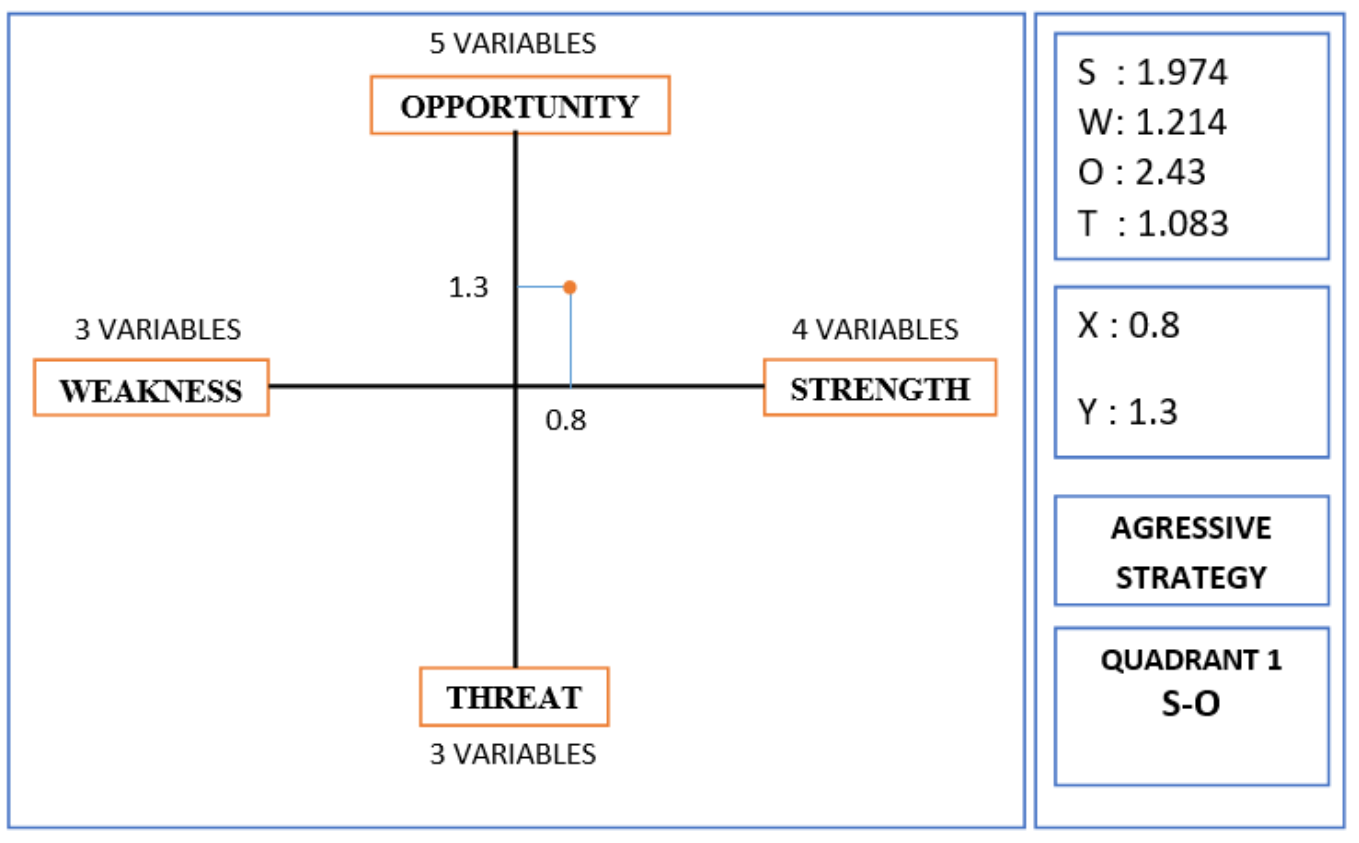

Figure 4. Matrix Grand Strategy

Then, for the form of communication strategy that can be used on Instagram is AISAS (Attention - Interest - Search - Action - Share). Step by Step using AISAS to introducing Ecotourism concept are Attention with using engagement such as using public figure or influencer in Instagram to spread the information, Interest with repost the information like 3 days in a row, after getting the interest, they will search to find out what happened and find ecotourism, Action will be taken by them with watching or see the information and then for the last part the will share the information to their social media to gain recognition from their follower [19]. This AISAS strategy will also provide engagement between users and ecotourism. Because if they share more of it, it will make ecotourism as a new trend or brand of tourism for young people and increasing sense of belonging [20]. This form will be very suitable to be applied to disseminate information about ecotourism especially for students.

\section{CONCLUSION}

From the research, it can be concluded that Instagram is the most used social media by students in Malang. And for the management strategy with Instagram, it can be done with an aggressive strategy that is utilizing excellence and Opportunities from Instagram such as fast, cheap, environmentally friendly and widely used by students. To be more optimal, later in using Instagram, we suggest to use the AISAS communication strategy approach with interesting content as an entrance to attract attention.

\section{REFERENCES}

[1] Sukara, E. and Tobing, I. S. L. 2008. Industri berbasis keanekaragaman hayati, masa depan Indonesia. VIS VITALIS 1(2), 1-12.

[2] Republic of Indonesia. 2009. Law No. 32 about Environment Protection and Management Article 1 Paragraph 9. Republic of Indonesia. Jakarta.

[3] Nugroho, I. and P. D. Negara. 2015. Pengembangan Ekowisata. PT. Era Adicitra Intermedia. Solo.

[4] Hakim, L. 2004. Dasar-dasar Ekowisata. Bayumedia Publishing. Malang.

[5] Cheng, M., I. A. Wong, S. Wearing and M. McDonald. 2017. Ecotourism social media initiatives in China. Journal of Sustainable Tourism 25(3), 416-432.

[6] Howard, P. N. and M. R. Parks. 2012. Social media and political change: capacity, constraint, and consequence. Journal of Communication 62(2), 359-362.

[7] Indonesian Internet Service Provider Association (APJII). 2016. Penetrasi dan perilaku pengguna internet Indonesia. Available at: https://apjii.or.id/downfile /file/surveipenetrasiinternet2016.pdf.

[8] Dong, T., Liang, C. and X. He. 2017. Social media and internet public events. Telematics and Informatics 34, 726-739. 
[9] Sarkar, S. K. 2016. Urban ecotourism destinations and the role of social networking sites; a case of Kuala Lumpur. ECOCLUB.com Ecotourism Paper Series Nr. 39. Available at: https://ecoclub.com/ images/papers/39.pdf.

[10] Xu, S., L. Mingzhu, N. Bu and S. Pan. 2017. Regulatory framework for ecotourism: an application of total relationship flow management theorems. Tourism Management 61, 321-330.

[11] Merdeka. 2016. Malang sebagai kota pendidikan sejak masa Hindia Belanda. Available at: https://malang.merdeka.com/ kabar-malang/malang-sebagai-kotapendidikan-sejak-masa-hindia-belanda160502n.html.

[12] Infokampus. 2017. Ini presentase kuota penerimaan mahasiswa UB tahun 2017 dari berbagai macam jalur. Availabel at: https://infokampus.news/ini-persentasekuota-penerimaan-mahasiswa-ub-tahun2017/.

[13] Sugiono. 2013. Metode penelitian kombinasi (mixed methods). Alfabeta Publisher. Bandung.

[14] Syamsuddin, A. R. \& Damaianti. 2011. Metode penelitian pendidikan bahasa. PT. Remaja Rosdakarya. Bandung.

[15] Sutopo, H. B. 2006. Metode penelitian kualitatif. Sebelas Maret University (UNS) Press. Surakarta.

[16] Cloudhost. 2016. Mengenal Google Form untuk kebutuhan survey anda. Available at: https://idcloudhost.com/mengenal-googleform-untuk-kebutuhan-survey-anda/.

[17] Purwanti, P., E. Susilo and E. Indrayani. 2017. Pengelolaan hutan mangrove berkelanjutan. University of Brawijaya Press. Malang.

[18] Techstory. 2016. 6 reasons behind the rise in popularity of Instagram. Available at: https://techstory.in/instagram-popularity/

[19] Saputra, D. 2017. AIDMA model and AISAS model in digital marketing stratgey. Bina Nusantara University. Jakarta. Available at: http://bbs.binus.ac.id/ibm/2017/06/aidmamodel-aisas-model-in-digital-marketingstrategy/.

[20] Rochman, E. A. and B. P. Iskandar. 2015. Users' engagement toward the brand accounts in Instagram based on the AISAS model. Journal of Business and Management 4(8), 890-900. 